\title{
Strategies of Increasing Local Taxes In The North Central Timor District
}

\author{
Yohanes B.D.Banu ${ }^{1}$, David B.W.Pandie ${ }^{2}$, Petrus Kase ${ }^{3}$ \\ Masters Program in Administration Science Nusa Cendana University ${ }^{1,2,3}$ \\ Email : azker100@gmail.com
}

(Received: October 24-2020; revised: November 24-2020; published: December 31-2020)

\begin{abstract}
This research was conducted to determine the strategy for increasing local taxes implemented by the Regional Revenue Agency of Timor Tengah Utara Regency. The results of this research show that the regional taxes of North Central Timor Regency have not been running optimally because of the 9 (nine) types of taxes not all of them have contributed to the Regional Original Income. A strategy for increasing local taxes through intensification and extensification is needed. Intensification includes 1) aspects of institutional arrangement, 2) aspects of management which include processing regional tax data, determining regional tax data as well as collecting and collecting local taxes. 3) personnel aspects. while the extensification aspect is related to data collection and verification as well as socialization of local taxes. Furthermore, the ratio of the contribution of local taxes to the regional revenue of North Central Timor Regency is still insufficient, the local taxes that contribute the most to local revenue are street lighting taxes while the least contributed taxes are groundwater taxes. In the implementation of regional taxes, there are several supporting factors in the form of the availability of adequate facilities and infrastructure, adequate budget and cooperation with State-Owned Enterprises (BUMN) and Regional-Owned Enterprises (BUMD), while the inhibiting factor is the low awareness of taxpayers, unscrupulous officials. dishonest and not yet integrated local tax information system with regional income.
\end{abstract}

Keywords: Local Taxes, Increasing Strategy, Local Own Income

\section{INTRODUCTION}

Law Number 23 of 2014 concerning Regional Government gave birth to a new government management concept in the regions, namely regional autonomy, regional autonomy is a momentum for regions to manage their own resources in the form of natural resources and human resources in order to create a prosperous society. The concept of regional autonomy offered to regions is full autonomy (broad, real and responsible), in which regions can use flexibility in managing and synergizing existing resources or potentials to accelerate economic growth and regional development.

Regional revenue is the right of the Regional Government which is recognized as an addition to net asset value in the period of the fiscal year concerned. This right includes all receipts of money through the regional general cash account, which adds to the equity of the fund and does not need to be paid back by the regions. Regional Revenue consists of 1. Original Regional Revenue (Regional taxes, regional levies, results of regional wealth management, and other legal regional income. 2 Balancing Funds (Tax Sharing / Non-Tax Profit Sharing, General Allocation Funds, and Allocation Funds) Specifically) the Balancing Fund aims to reduce the imbalance of funding sources between the Central Government and Regional Governments, as well as reduce 
Yohanes B.D.Banu, David B.W.Pandie, Petrus Kase; Strategies of Increasing Local ... $\mid 455$

the gaps in government funding between regions; 3. Other Legitimate Regional Revenues (grant revenue, provincial tax revenue sharing and adjustment funds).

Revenue received from the North Central Timor Regency in the 2018 and 2109 Fiscal Years did not experience significant changes, the realization of regional income originating from regional original revenue in the 2019 Fiscal Year increased by $10.34 \%$ from the 2018 Fiscal Year, the balance of funds income in the 2019 Fiscal Year decreased by 3.08\% from Fiscal Year 2018 and then Other Legitimate Regional Income decreased by $0.82 \%$ from Fiscal Year 2018. In total, revenue realization in Fiscal Year 2019 decreased by 1.82\% from Fiscal Year 2018.

The first component of regional revenue is local revenue, local revenue. Regional financial policies are directed at increasing local revenue as the main source of regional income that can be used by regions in implementing regional governance and development according to their needs in order to reduce dependence on central government transfer funds through balancing fund.

One source of regional revenue is regional taxes, which constitute mandatory contributions to the region owed by private persons or entities of a coercive nature based on law, without receiving direct compensation and used for regional needs for the greatest prosperity of the people. District / city local taxes as regulated in Law Number 28 of 2009 are as follows: Hotel Tax, Restaurant Tax, Entertainment Tax, Advertising Tax, Street Lighting Tax, Non-Metal Mineral and Rock Tax, Parking Tax, Ground Water Tax, Tax. Swallow's Nests, Rural and Urban Land and Building Tax, and Land and Building Acquisition Fees. With due observance of the above regional taxes, in its implementation by paying attention to its potential and characteristics, the swallow's nest tax and parking tax are not implemented in North Central Timor Regency.

Furthermore, as a result of not achieving the predetermined regional tax targets, the regional tax receivables are increasing, according to Regional Regulation Number 5 of 2011 concerning Regional Taxes in North Central Timor Regency, Regional Tax Receivables are the amount of money that must be paid to the Regional Government and or the rights of the Regional Government can be valued in cash as a result of non-payment of local taxes listed in the Tax Returns Payable (SPPT), Regional Tax Determinations (SKPD), Regional Tax Bills (STPD).

Regional tax receivables up to January 1, 2019 amounting to Rp. 4,432,880,900.74 (four billion four hundred and thirty-two million eight hundred eighty thousand nine hundred rupiah and seventy-four cents) while the actual payment of receivables until December 31, 2019 is Rp. 462,572,645.18 (four hundred sixty-two million five hundred seventy-two thousand six hundred forty-five rupiah and eighteen cents). The PBB-P2 tax and mineral and non-metal and rock taxes were the largest contributors to the accounts receivable, respectively as much as Rp. 2,770,921,435.12 and Rp. 1,266,406,443.62. Based on the data above, the regional tax receivables of Timor Tengah Utara Regency are still very large and must be collected by the Regional Revenue Agency of Timor Tengah Utara Regency as well as the low awareness of taxpayers to pay off these receivables.

Seeing the above phenomena, of course, there are internal and external problems that affect the implementation of local taxes in North Central Timor Regency. This condition shows that there is an imbalance in the implementation of local taxes. Collecting money from local taxes is not an easy job, so a high awareness is needed by the taxpayer community in carrying out their tax obligations, supported by the Regional Revenue Agency of Timor Tengah Utara Regency which is innovative and creative in managing the regional tax. 


\section{Jurnal Ilmiah Ilmu Administrasi Publik: Jurnal Pemikiran dan Penelitian Administrasi Publik \\ Volume 10 Number 2, July-December 2020. Page 454-465}

\section{METHOD}

This study uses a qualitative research design, the focus of this research is as follows: 1) Implementation of local taxes in North Central Timor Regency, 2) Strategies for increasing local taxes with sub-focus a) Intensification of local taxes consisting of institutional aspects, management aspects (data processing local tax, local tax determination, collection and collection of local taxes and local tax receivables) and personnel aspects. b) Extensification of local taxes includes data collection and verification of objects as well as socialization of local taxes. 3) Supporting factors and inhibiting factors for increasing regional taxes in North Central Timor Regency. The data collection techniques in this study were interviews, observation and document study, while the data analysis techniques were Miles and Huberman. Sugiono (2002).

\section{RESULT AND DISCUSSION}

\section{Regional Tax Implementation Of North Central Timor District}

According to Mardiasmo (2009: 12), taxes are mandatory contributions made by individuals or entities to the regions without a balanced direct reward, which can be enforced based on the prevailing laws and regulations, which are used to finance the implementation of regional governance and regional development. Furthermore, according to Davey (Prakosa 2005; 2), the criteria for regional taxes consist of 4 (four) things, namely 1). Taxes collected by local governments based on the regulation of their own regions; 2). Taxes that are collected based on central government regulations, but the rate is determined by local governments; 3). Taxes determined and or collected by local governments; 4). Taxes collected and administered by the central government but the results of these collections are given to local governments. In accordance with the mandate of Law 28 of 2009 concerning Regional Taxes and Regional Levies and Regional Regulation of North Central Timor Regency Number 5 of 2011 concerning Regional Taxes. There are 9 (nine) local taxes implemented in North Central Timor Regency. As can be seen in table 1 below:

Table 1

TARGET AND REALIZATION OF REGIONAL TAXES OF TTU REGENCY 2017 S / D 2019

\begin{tabular}{|c|c|c|c|c|c|c|}
\hline \multirow[t]{2}{*}{ NO } & \multirow{2}{*}{$\begin{array}{l}\text { LOCAL } \\
\text { TAX }\end{array}$} & \multirow{2}{*}{$\begin{array}{c}\text { TARGET } 2017 \text { - } \\
2019\end{array}$} & \multicolumn{3}{|c|}{ REALIZATION } & \multirow[t]{2}{*}{ TOTAL } \\
\hline & & & 2017 & 2018 & 2019 & \\
\hline 1 & $\begin{array}{l}\text { Street } \\
\text { Lighting Tax }\end{array}$ & $6.018 .804 .408,06$ & $2.221 .050 .660,00$ & $2.857 .499 .033,00$ & 2.881.238.507,00 & 7.959.788.200,00 \\
\hline 2 & $\begin{array}{l}\text { Metal, Non } \\
\text { Metal and } \\
\text { Rock Mineral } \\
\text { Tax }\end{array}$ & $6.700 .000 .000,00$ & $2.360 .370 .105,00$ & $2.147 .837 .739,00$ & $1.304 .078 .678,00$ & $5.812 .286 .522,00$ \\
\hline 3 & property tax & 7.908.452.387,89 & $1.593 .509 .057,00$ & $1.396 .035 .815,00$ & $1.621 .745 .832,00$ & 4.611.290.704,00 \\
\hline 4 & Restaurant tax & $1.447 .946 .099,32$ & $876.920 .595,00$ & $1.126 .683 .833,00$ & $1.365 .950 .594,00$ & $3.369 .555 .022,00$ \\
\hline
\end{tabular}


Yohanes B.D.Banu, David B.W.Pandie, Petrus Kase; Strategies of Increasing Local ... |457

\begin{tabular}{rlrrrrr}
\hline $\mathbf{5}$ & $\begin{array}{l}\text { Tax on } \\
\text { Acquisition of } \\
\text { Rights on } \\
\text { Land and } \\
\text { Buildings } \\
\text { (BPHTB) }\end{array}$ & $240.000 .000,00$ & $234.168 .812,00$ & $441.437 .875,00$ & $489.660 .150,00$ & $1.165 .266 .837,00$ \\
\hline $\mathbf{6}$ & $\begin{array}{l}\text { Advertisement } \\
\text { tax }\end{array}$ & $438.351 .952,13$ & $172.560 .786,00$ & $177.811 .635,00$ & $175.545 .477,00$ & $525.917 .898,00$ \\
\hline $\mathbf{7}$ & Hotel Tax & $126.650 .000,00$ & $37.850 .000,00$ & $48.150 .000,00$ & $110.600 .000,00$ & $196.600 .000,00$ \\
\hline $\mathbf{8}$ & $\begin{array}{l}\text { Entertainment } \\
\text { Tax }\end{array}$ & $2.910 .000,00$ & $1.155 .000,00$ & - & $1.175 .000,00$ & $2.330 .000,00$ \\
\hline $\mathbf{9}$ & $\begin{array}{l}\text { Groundwater } \\
\text { Tax }\end{array}$ & $10.375 .000,00$ & - & - & - & - \\
\hline & AMOUNT & $\mathbf{2 2 . 8 9 3 . 4 8 9 . 8 4 7 , 4 0}$ & $\mathbf{7 . 4 9 7 . 5 8 5 . 0 1 5 , 0 0}$ & $\mathbf{8 . 1 9 5 . 4 5 5 . 9 3 0 , 0 0}$ & $\mathbf{7 . 9 4 9 . 9 9 4 . 2 3 8 , 0 0}$ & $\mathbf{2 3 . 6 4 3 . 0 3 5 . 1 8 3 , 0 0}$ \\
\hline
\end{tabular}

Source : Bapenda Kab.TTU 2020

Based on the data in table 1, it can show that from the 2017-2019 fiscal year the total contribution of regional taxes to regional income and local revenue is Rp. 23,643,035,183, respectively, it can be explained that 1) Street lighting tax is a tax that provides the most significant contribution to local revenue from the 2017 to 2019 fiscal year, amounting to IDR $7,959,788,200$ or $36.24 \%$ of total local taxes. 2) Non-metal mineral and rock tax amounting to Rp. 5,812,286,522 or $24.70 \%$ of the total local tax. 3) Land and building tax of Rp. 4,611,290,704 or $19.56 \%$ of the total local tax. 4) Restaurant tax amounting to Rp. 3,369.55,022 or $14.21 \%$ of the total local tax. 5) BPHTB of Rp. 1,165,266,837 or 4.89\% of the total local tax. 6) Advertising tax of Rp. 525,917,898 or $2.23 \%$ of total local taxes. 7) Hotel tax of Rp. 196,600,000 or $0.83 \%$ of the total local tax. 8) Entertainment tax Rp. 2,330,000 or 0.01\% of the total local tax. 9) Ground water tax is not realized at all.

The results of the intensification and extensification of local taxes on the accumulation of regional taxes in North Central Timor Regency have not been running optimally because the institutions at the TTU Regency Bapenda still show ego fields and overlapping tasks and functions, then related to management which includes data processing, data determination, local tax collection and Perosnil can the author convey that data processing and determination of local tax data have used a management information system in the form of SISMIOP and SIMPARESDA and are running well so that it makes it easier for the apparatus to produce good and correct local tax data, these data become the basis for collecting and collecting local taxes. Local tax collection activities are not easy, depending on the awareness of taxpayers and also the behavior of officials in collecting and collecting local taxes.

The process of data collection and verification as well as exploring the potential for regional taxes has been running well but it cannot be denied that there are several types of taxes that have not been properly explored, for example taxes on non-metal minerals and rocks if we look at the number of rivers / streams in North Central Timor Regency and also mengeliatnya development both carried out by individuals and third parties will certainly be able to encourage an increase in local taxes. To make taxpayers aware, of course, it is necessary to do socialization related to local taxes to the public with interesting materials using social media, pamphlets and interesting leaflets so as to inspire taxpayers to register and deposit their tax obligations. 


\section{8 | Jurnal Ilmiah Ilmu Administrasi Publik: Jurnal Pemikiran dan Penelitian Administrasi Publik \\ Volume io Number 2, July-December 2020. Page 454-465}

\section{Strategy For Increasing Regional Taxes Strategy Concept}

According to Chandler (Rangkuti 2013) Strategy is a tool to achieve company goals in relation to long-term goals, follow-up programs, and resource allocation priorities. Furthermore, Rangkuti (2013) states that strategy is a comprehensive master plan, which explains how the company will achieve all the goals that have been set based on the mission that has been previously set. According to Siagian (2002: 16) states that strategy is an accurate analysis of the strengths of the organization, the weaknesses that may be attached to itself, various opportunities that may arise and must be exploited and the threats that are expected to be faced.

\section{Fiscal Decentralization}

According to Litvack (1999), decentralization includes aspects of politics (political decentralization), administrative (administrative decentralization), and fiscal (fiscal decentralization).

a. Political decentralization, the delegation of greater authority to regions concerning aspects of decision making, including setting standards and various regulations.

b. Administrative decentralization is the delegation of authority, responsibility and resources between various levels of government

c. Fiscal decentralization, is the granting of authority to regions to explore sources of income, the right to receive transfers from higher governments, and determine routine expenditure and investment.

Saragih (2003: 83) explains that fiscal decentralization can be defined as a process of distributing budgets from higher levels of government to lower levels of government, to support government functions or tasks and public services in accordance with the amount of authority in the field of government being delegated.

\section{Regional Financial Independence}

According to Halim (2002), regional financial independence shows that local governments are able to self-finance government activities, development and services to people who have paid taxes and levies as a source of revenue needed by the region. Furthermore, Widodo (2001: 262) states that the ratio of Regional Financial Independence shows the level of ability of a region to self-finance government activities, development and services to people who have paid taxes and levies as a source of revenue needed by the region. The ratio of independence is shown by the amount of local revenue compared to regional revenue from other sources (external parties), including: tax sharing, non-tax revenue sharing for natural resources, general allocation center fund and special allocation center fund, emergency center fund and the Central Loan Fund. In increasing local revenue through local taxes, the North Central Timor Regency Government has taken several steps including: 
Yohanes B.D.Banu, David B.W.Pandie, Petrus Kase; Strategies of Increasing Local ... $\mid 459$

\section{A. Local Tax Intensification}

Regional tax intensification is an activity carried out to increase the amount of revenue from taxpayers who are registered as regional taxpayers. The process of implementing regional tax intensification activities is related to institutional aspects, aspects of management/ implementation of regional taxes and aspects of personnel implementing local taxes.

1. Institutional Aspects: One of the strategies to increase local taxes is to be supported by good institutional institutions, because with good institutional conditions, the implementation of tasks and functions in order to increase regional taxes in North Central Timor Regency will be easier and more focused. The Head of North Central Timor Regency has changed the job description, organizational structure function through North Central Timor Regent Regulation Number 92 of 2019 concerning amendments to the North Central Timor Regent Regulation Number 71 of 2016 Regulation concerning Position, Organizational Structure, Duties and Functions as well as Agency Work Procedures Regional Income. the institutional condition of regional revenue agencies has not shown a balance of duties and distribution of the budget, which in certain fields of activity is quite large so that the budget is also large. Meanwhile, there are other fields that have few tasks even though they have large responsibilities but only a small budget is given. This condition greatly influenced the increase in local taxes in North Central Timor Regency.

2. Aspects of Management : A series of processes carried out within the organization in order to achieve organizational goals effectively and efficiently. Organizational management that needs to be developed is to create working relationships between officials and across regional officials by fostering a sense of togetherness and partnership in carrying out duties and responsibilities in order to increase local taxes. As for things that include aspects of management that the author will research related to:

* Local Tax Data Processing : The management of regional tax data is an important aspect in increasing local taxes because with good and correct data management, the potential for existing local taxes will not be miscalculated at the time of its determination. The management of regional tax data in Timor Tengah Utara Regency is carried out in 2 (two) ways, namely manually and using a management information system. As for manually on several types of taxes, including NonMetal Mineral and Rock Tax, BPHTB and Street Lighting Tax, while those who have used the Management Information System in the form of Urban and Rural Land and Building taxes with the Tax Object Management Information System (SISMIOP) and Advertising Tax, hotel tax, restaurant tax and entertainment tax with the application of the Regional Tax and Retribution Management Information System (SIMPARESDA).

* Local Tax Determination : The fundamental difference between the selfassessment system and the official assessment system is related to the determination of regional taxes. With the official assessment system, the payment of local taxes in Timor Tengah Utara Regency is preceded by the issuance of a Regional Tax Assessment for PBB-P2, Advertising Tax and Groundwater Tax. Payable Tax Return (SPPT) for PBB-P2. Meanwhile, there are several local taxes that do not require regional tax assessments such as Restaurant Tax, Hotel Tax, Non-Metal Mineral and Rock Tax and Entertainment Tax because the collection 


\section{Jurnal Ilmiah Ilmu Administrasi Publik: Jurnal Pemikiran dan Penelitian Administrasi Publik \\ Volume io Number 2, July-December 2020. Page 454-465}

system is self-assessment where the taxpayer calculates, pays and reports the tax concerned, while the duties of the Regional Income Agency are to verify reports whether based on actual data or not.

* Local Tax Collection and Collection: The collection and collection of taxes by the North Central Timor Regency Regional Revenue Agency are carried out by 2 (two) teams. The First Team handled hotel tax, restaurant tax, advertisement tax, entertainment tax and PBB-P2, the Second Team handled non-metal mineral and rock taxes located at Integrated Posts and also river banks, as for street lighting tax and BPHB, there were no billing and collection. . Meanwhile, ground water tax has not been implemented. Furthermore, the author will dissect and analyze the implementation of billing and collection of local taxes in North Central Timor Regency.

In relation to PBB-P2, the author can explain that after the conversion to regional taxes in 2014 , the regions practically struggled on their own to increase the PBB-P2 results, habits that have been obtained such as collection wages and incentives cannot be implemented anymore now because of the limitations of regional financial capacities. Policies prior to the transfer of collector officers receive collection wages and incentives from the central government. This condition is of course a problem in the collection and collection of PBB-P2.The bill of tax on advertisements has been going well so far, but there are some taxpayers who are unwilling to pay the expensive billboards designation because they match the size of the billboards and the location of the billboards. In addition, there are third parties / mandatory billboards that put up billboards, but their domicile is not in North Central Timor Regency but outside, making it difficult for officers to collect them.Collection of hotel tax and restaurant tax is usually carried out by officers at the location of business.

In general, regarding the two taxes, if we see that the results are not optimal because if we look at the activities of hotels and restaurants in North Central Timor Regency before the pandemic, it was very developed and according to the author, there are people who own hotels and restaurants who are not honest in submitting their taxes. The Regional Government of North Central Timor Regency through the Regional Revenue Agency is collaborating with NTT Bank regarding the installation of 10 (ten) POS (Point Of Sales) units or online cashiers that can be connected to the Bank's server and the Regional Revenue Agency for transactions and deduction of local taxes. reported accurately. So far this tool has not been installed, but the enthusiasm and innovation that exists is a step forward that needs to be appreciated because changing an old habit to a good thing requires extraordinary enthusiasm, it is planned that this tool will be installed in restaurants and hotels.

Entertainment tax in North Central Timor Regency is usually at fitness centers, children's games such as odong-odong and billiards, but implementation in North Central Timor Regency has not been going well because based on observations and documents the author of the analysis turns out to be taxpayers. Entertainment only pays entertainment tax only once a year. The basis for the imposition of entertainment tax is the amount of money received or that should be received by entertainment providers each time they organize entertainment.Furthermore, related to the non-metal mineral and rock tax, the author can explain that the basis for printing non-metal 
Yohanes B.D.Banu, David B.W.Pandie, Petrus Kase; Strategies of Increasing Local ... $\mid 461$

minerals and rocks tax is the Regent of TTU Decree Number 5 / KEP / HK / I / 2020 concerning Standard Pricing of Non-Metal Mineral and Rock Types of Tax in the Regency. North Central Timor. This decision is an amendment from the Regent of TTU Decree Number 104 / KEP / HK / III / 2016 Determination of Standard Tax Prices for Non-Metal Mineral and Rock Types in North Central Timor Regency.

This policy is one of the strategies of the local government in encouraging an increase in taxes on non-metal minerals and rocks. Usually after the collection and collector officers at the integrated post and riverbanks recap the ticket book and submit it to the head of the sub-division for determining other regional taxes to be determined by a regional tax assessment letter.Furthermore, regarding the collection and collection of Street Lighting Tax (PPJ), it is carried out based on the Cooperation Agreement between the North Central Timor Regency Government and PT. PLN (PERSERO) East Nusa Tenggara Regional Main Unit UP3 Kupang which contains the related obligations of PT PLN to cut and collect street lighting tax from electricity customers who charge electric pulses and then deposit the account to the Regional Treasury, with the consideration of PT. PLN (PERSERO) East Nusa Tenggara Regional Main Unit UP3 Kupang assists the government in submitting PPJ payment / deposit reports and detailed information including recapitulation of electricity bills printed per tariff type, number of subscribers, number of $\mathrm{KWh}$, amount of $\mathrm{KWh}$, recapitulation of PPJ revenue realization per tariff type , and other relevant data, while the North Central Timor District Government is obliged to disseminate information to the public (customers) regarding Street Lighting Tax, collection authority, tariffs and the use of this tax.

3. Personnel Aspects Regional tax personnel are people who are in charge of collecting data, registering, processing data, stipulating, invoicing, paying, reporting, and supervising administrative processes related to regional taxes. An apparatus who collects regional tax data must know the criteria for a person who can be designated as a regional taxpayer. Because not everyone can be designated as a regional taxpayer because they must understand the criteria. In addition, to process data and determine local taxes, an apparatus is required to have expertise in calculating and analyzing data on existing regional tax potentials and has the ability to use computers so that people who have been determined to be local taxpayers do not object to the taxes imposed. Furthermore, related to the ability of the apparatus to collect and collect local taxes, the author can say that this task is certainly the most difficult to carry out because the characteristics of each taxpayer are different, but the technicalities in the field are based on the observations made by the author, generally the collection activities carried out run smoothly. fluent even though sometimes the collection officer received verbal harsh treatment.

\section{B. Local Tax Extensification}

Extensification is carried out by means of data collection and verification of regional taxes and dissemination of applicable regulations and provisions related to regional taxes to business actors whose businesses are the object of regional taxes and have not been registered and have not carried out their tax obligations so that business actors immediately register themselves as regional taxpayers. 


\section{Jurnal Ilmiah Ilmu Administrasi Publik: Jurnal Pemikiran dan Penelitian Administrasi Publik \\ Volume io Number 2, July-December 2020. Page 454-465}

\section{Data collection and verification of local taxes}

The implementation of data collection and verification in order to explore the potential of the region to become regional taxes is strongly influenced by the availability of budget and supporting facilities, while the activities of data collection and verification of objects and subjects of regional taxes are intended to create an accurate database. The objectives are to carry out data collection and verification of objects and subjects of regional taxes in order to create a regional tax database, orderly administration, increase the principal of regional tax provisions, impose more equitable and equitable charges, improve services to taxpayers.

Data collection and verification of local tax data have their own ways according to the type of tax, but the most basic is the stages of data collection and verification, which are the most crucial in increasing local taxes because they relate to the multiplication of potential taxes, both existing and new tax objects. If the data provided is wrong or erroneous, it will have a considerable impact on the determination of local taxes and also the collection and collection of local taxes.

\section{Socialization of local taxes}

Tax dissemination is a strategy to provide insight, understanding, information and guidance to the public in general and taxpayers in particular so that they know everything about taxation and tax laws carried out by competent agencies. Socialization can increase knowledge about taxes which in turn can have an impact on increasing the awareness of taxpayers themselves. The socialization carried out by the North Central Timor Regency Regional Revenue Agency is in the form of 1.) Inclusion of identity by means of leaflets, banners and stickers at strategic places and stalls, hotels and other business places. 2) Activities (events) in the form of socialization activities, counseling and appeals to the community in the sub-districts in North Central Timor Regency.

\section{Supporting Factors and Inhibiting Factors for Increasing Local Taxes}

In the implementation of the increase in regional taxes in the Regency of North Central Timor, based on the author's observations, there are several supporting and inhibiting factors, while the supporting factors for regional taxes are things that are encouraging, stimulating, smoothing, supporting, assisting, accelerating the increase in local taxes besides the inhibiting factors are things that inhibit or even hinder the increase in local taxes.

\section{Supporting Factors}

1. The existence of central and local government regulations related to local taxes. Regulation is the basis for local governments to carry out tax activities. The regulations are in the form of laws, regional regulations, regent regulations and decrees of the Regent of North Central Timor.

\section{Availability of local tax increase budget.}

The budget is a provision that is used by the apparatus to record and verify regional taxes, process regional tax data and coordinate and collect local taxes. Ideally, the amount of tax earned should be greater than the total expenditure for activities to increase local taxes. 
Yohanes B.D.Banu, David B.W.Pandie, Petrus Kase; Strategies of Increasing Local ... $\mid 463$

\section{Security support}

In the case of local tax collection, of course, the apparatus needs to be assisted by the security forces, both from the Police and the TNI, actually the aim is not to intimidate but to ensure the security of collection officers who are at integrated posts because technically these posts are located at Regency boundaries. North Central Timor

4. Adequate facilities and infrastructure

The facilities and infrastructure at the Bapenda of TTU Regency, according to the author's observations, are very adequate to increase local taxes ranging from buildings, vehicles, servers etc.

5. Support from BUMN and BUMD.

BUMN cooperation in this case PT. PLN (PERSERO) East Nusa Tenggara Regional Main Unit UP3 Kupang with the North Central Timor Regency Government in the form of collecting street lighting tax. Furthermore, the cooperation of Regional Owned Enterprises, in this case Bank NTT, Kefamenanu Branch, is in the form of procurement of point of sales devices or online cashiers and payment of tax vendor administration.

6. The strategic location of Timor Tengah Utara Regency.

North Central Timor Regency is very strategic because it is located in the middle of the Timor Island because it is flanked by 4 (four) Regencies and 1 (One) country so that it becomes a transit point for those traveling overland.

\section{Obstacle Factor}

1. Unintegrated local tax data base.

Regional tax database that has not been integrated with the regional revenue management system. Whereas the data base is very decisive for testing the accuracy of the target and realization of local taxes.

2. There are officers who are dishonest.

Taxpayers are often the target of errors when the level of taxpayer compliance is low, which disrupts the realization of tax revenue. Whereas in the taxation system, the taxpayer is not a single actor but the existence of a taxpayer is accompanied by a tax official. There are several Bapenda officers who are not honest in carrying out their duties to collect and collect taxes.

3. There are no collection wages and local tax incentives.

Since PBB-P2 has become a regional tax, since then there have also been no collection of wages and incentives for the apparatus, from the district to the RT level. This condition greatly affects the morale of the apparatus in collecting taxes because according to them the work they do is useless and not appreciated. Related to this, of course, the thing to pay attention to is efficiency in collecting taxes.

4. Low awareness and understanding of taxpayers

Taxpayer awareness is often associated with the desire and compliance in carrying out tax rights and obligations in accordance with applicable regulations

5. The control system is not optimal

Regional taxpayers who do not pay taxes are not sanctioned by the Bapenda of TTU Regency, giving rise to the idea that it is okay not to pay.

6. There are taxpayers who are not willing to cooperate with the government. 


\section{Jurnal Ilmiah Ilmu Administrasi Publik: Jurnal Pemikiran dan Penelitian Administrasi Publik \\ Volume io Number 2, July-December 2020. Page 454-465}

There are unscrupulous owners of food stalls and hotels who do not want to cooperate in terms of installing an online cashier as a result of cooperation between the TTU Regency Government and the Kefamenanu Branch of the NTT Bank.

\section{CONCLUSION}

1. Implementation of regional taxes in the North Central Timor Regency

The regional taxes of North Central Timor Regency consist of 9 (nine) types but those that have contributed to Regional Original Revenue amounted to 8 (eight) types while the groundwater tax has not been implemented because the regent's regulation regarding implementation instructions related to the tax has just been enacted and has not been socialized.

2. The strategy for increasing local taxes in Timor Tengah Utara Regency

The strategy undertaken by the Bapenda of Timor Tengah Utara Regency is to increase local taxes through intensification and extensification of regional taxes. The intensification through regional tax intensification consists of institutional aspects, management aspects and personnel aspects. Furthermore, related to extensification, it is carried out by collecting data and verifying local taxes and disseminating applicable regulations and provisions related to regional taxes.

3. Supporting and inhibiting factors for increasing local taxes in North Central Timor District. The supporting factors are in the form of central and regional government regulations related to local taxes, support with sufficient budget from local governments, support from external stakeholders in this case the TNI and Polri from the security side and support from BUMN PT. PLN (PERSERO) East Nusa Tenggara Regional Main Unit UP3 Kupang to the North Central Timor Regency Government in the form of street lighting tax collection and BUMD BANK in the form of a point of sales device or online cashier.

Furthermore, related to the inhibiting factors, the lack or absence of public awareness as taxpayers to pay local taxes, there are unscrupulous officers of the TTU Regency Bapenda, the regional tax database that has not been integrated with the regional revenue management system to test the correctness of the tax payment, lack of socialization and comparative studies related to the implementation of local taxes, there are no collection wages and local tax incentives. Lack of local tax socialization, even if there is any form of socialization carried out, it is only in the form of meetings with the community at the sub-district office. This form of socialization needs to be evaluated so that it gets other forms that are more inspiring for the public to pay local taxes.

\section{REFERENCE}

Halim, Abdul.2002. Akuntansi Sektor Publik akuntansi Keuangan Daerah Edisi Pertama.Salemba empat:Jakarta.

Litvack, 1999. Decentralization. World Bank:Washington DC 
Yohanes B.D.Banu, David B.W.Pandie, Petrus Kase; Strategies of Increasing Local ... $\mid 465$

Mardiasmo.1999. Pengelolaan Keuangan Daerah yang Berorientasi Pada Kepentingan Publik. PAU Studi Ekonomi UGM:Yogyakarta.

Prakosa, Bambang Kesit. 2005. Pajak dan Retribusi Daerah. UII Press:Yogyakarta.

Rangkuti, Freddy. 2013. Strategi Semut Melawan Gajah.Gramedia Pustaka Utama: Jakarta.

Saragih, Juli Panglima. 2003. Desentralisasi Fiskal dan Keuangan Daerah dalam Otonomi. Penerbit Ghalia Indonesia; Bogor.

Sugiyono. 2002. Metode Penelitian Administrasi. Bandung : CV Alfabeta

Siagian, S.P. 2002. Menejemen strategik.PT. Bumi Askara: Jakarta

Widodo, Joko. 2001. Good Governance: Telaah dari Dimensi: Akuntabilitas dan Kontrol Birokrasi pada Era Desentralisasi dan Otonomi Daerah. Insan Cedekia:Surabaya. 